\title{
Smoking and Asthma
}

\author{
Megan Stapleton, PharmD, Amanda Howard-Thompson, PharmD, BCPS, \\ Christa George, PharmD, BCPS, CDE, Robert M. Hoover, MD, \\ and Timothy H. Self, PharmD
}

Background: The purpose of this review is to describe the current understanding of the prevalence and adverse effects of cigarette smoking and secondhand smoke (SHS) in asthmatics in terms of patient outcomes and response to inhaled corticosteroids.

Methods: We searched the English biomedical literature via PubMed, Embase, and Scopus using the terms "smoking and asthma," "secondhand smoke and asthma," "environmental tobacco smoke and asthma," and "smoking/secondhand smoke and corticosteroids." We also reviewed reference lists of identified articles for relevant citations.

Results: In asthmatic patients who smoke, disease control is poorer than in asthmatic nonsmokers. Of all forms of SHS, maternal exposure seems to have the largest impact on asthma by increasing the frequency and severity of the disease and decreasing lung function. Asthmatic children exposed to multiple household smokers face an increased risk for respiratory illness-related absences from school, and these effects persist during adolescence but weaken during adulthood. Airway mucosal permeability is increased in smokers, which could lead to increased clearance of inhaled corticosteroids from the airways. Smokers also have decreased histone deacetylase activity, which is necessary for corticosteroids to fully suppress cytokine production, and can lead to corticosteroid resistance.

Conclusions: Cigarette smoking and SHS in asthmatics lead to detrimental effects in patient outcomes and effectiveness of steroid therapy. (J Am Board Fam Med 2011;24:313-322.)

Keywords: Asthma, Inhaled Corticosteroid Resistance, Secondhand Smoke, Smoking

Asthma is an inflammatory airway disease that involves both airway inflammation and impaired airflow, and it affects 22 million Americans. Airway inflammation in asthma involves a very complex interaction of cells, mediators, cytokines, and chemokines. Immune and nonimmunologic environmental factors are important triggers of asthma, including cigarette smoking and secondhand smoke (SHS). ${ }^{1}$ Approximately $25 \%$ to $35 \%$ of individuals with asthma are current smokers. ${ }^{2}$ It is well-docu-

This article was externally peer reviewed.

Submitted 2 August 2010; revised 23 November 2010; accepted 7 December 2010.

From the Department of Clinical Pharmacy, Texas Tech University Health Science Center, Dallas (MS); and the Departments of Clinical Pharmacy (AH-T, CG, THS) and Family Medicine (AH-T, RMH), University of Tennessee Health Science Center, Memphis.

Funding: none.

Conflict of interest: none declared.

Corresponding author: Amanda Howard-Thompson, PharmD, Departments of Clinical Pharmacy, University of Tennessee Health Science Center, 1301 Primacy Parkway, Memphis, TN 38119 (E-mail: amhoward@uthsc.edu). mented that smoking or exposure to SHS among asthmatics increase asthma-related morbidity and disease severity. ${ }^{1}$ Prolonged exposure to tobacco smoke in patients with asthma contributes to a decline in lung function: approximately $18 \%$ in forced expiratory volume in 1 second $\left(\mathrm{FEV}_{1}\right)$ over 10 years. $^{3}$ Asthmatic patients who smoke share features similar to those found in the early stages of emphysema. ${ }^{4}$ Key mechanisms of the detrimental effects of smoking in patients with asthma are listed in Table 1.

The purpose of this review is to assess the recent (1994-2009) literature on this subject and relate current evidence regarding the prevalence of smoking and SHS exposure among asthmatics and their negative effects on patient outcomes. In addition, the effects of smoking and SHS on response to inhaled corticosteroids are summarized. The foundation of this review article started as grand rounds and was found to be of considerable importance because of the breadth of evidence and lack of 
Table 1. Examples of Mechanisms of Smoking and Airway Damage in Asthma

\begin{tabular}{ll}
\hline Mechanisms & References \\
\hline $\begin{array}{l}\text { Toxin direct to the bronchial epithelium, } \\
\quad \text { causing oxidative damage }\end{array}$ & 5 \\
$\begin{array}{l}\text { Release of proinflammatory mediators and } \\
\quad \text { increased epithelial permeability }\end{array}$ & 6 \\
Proinflammatory mediators and cytokines & \\
$\quad$ involved & \\
Interleukin-8 & $7-9,10$ \\
Lipopolysaccharides & 11 \\
Leukotriene B4 & 7,10 \\
Prostaglandin $\mathrm{E}_{2}$ & 12 \\
Angiopoietin-2 & 13 \\
Eotaxin-1 & 14 \\
\hline
\end{tabular}

literature discussing it in family medicine journals. Family medicine physicians are not only the primary health professionals involved in patients' general health care, but they also have the luxury of seeing the family as a whole, making them the ideal candidates to counsel and discuss the effects of primary smoking and SHS exposure on their asthmatic patient population.

\section{Methods}

We searched the English biomedical literature via PubMed, Embase, and Scopus using the terms "smoking and asthma," "secondhand smoke and asthma," "environmental tobacco smoke and asthma," and "smoking/secondhand smoke and corticosteroids." We also reviewed reference lists of identified articles for relevant citations.

\section{Risk of Asthma Development from Primary Smoking}

The risk of developing asthma was significantly higher among current smokers and among exsmokers compared with those who have never smoked (adjusted odds ratio [OR], 1.33 and 1.49, respectively) in an investigation by Piipari et al. ${ }^{15}$ Their results support the hypothesis that smoking causes asthma in adulthood. In addition, they found that women may be more susceptible to the adverse effects of smoking. It is debated whether smoking induces the development of asthma in adolescents. In a prospective cohort study including 2609 children with no lifetime history of asthma, Gilliland et $\mathrm{al}^{16}$ discovered that children who were nonsmokers without any history of allergy at study entry and who became regular smokers later in life were 5.2 times more likely to develop asthma; however, among those with a history of allergy there was little evidence of increased risk.

\section{Poor Control of Asthma Because of Primary Smoking}

Several investigators have found that asthmatic patients who smoke are more likely to have poorer disease control compared with asthmatic nonsmokers. ${ }^{17-20}$ A survey of 2269 asthmatic patients enrolled in a health maintenance organization showed that smoking was significantly and inversely related to long-term control of asthma (OR, 2.6; 95\% CI, 2.0-3.4). ${ }^{17}$ McCoy et $\mathrm{al}^{18}$ showed that asthmatic smokers older than age 10 were more likely to experience an episode of poor asthma control versus asthmatic nonsmokers (OR, 1.785; 95\% CI, 1.119-2.847). In 2007, a telephone survey of 11,962 asthmatic adults in the United States revealed that those who currently smoked reported more asthma attacks (OR, 1.2; 95\% CI, 1.0-1.4) and more nocturnal asthma symptoms (OR, 2.0; 95\% CI, 1.4-2.7) during the past 30 days than those who did not smoke. ${ }^{19}$ Chaudhuri et al ${ }^{20}$ reported that asthmatic smokers had significantly higher scores overall (OR, 2.8; 95\% CI, 1.7-3.4) and for each individual asthma symptom on the Juniper Asthma Control Questionnaire, indicating poorer disease control compared with asthmatic nonsmokers. The association between smoking and poor asthma control has also been reported in studies conducted in Canada, France, and Switzerland. $^{21-23}$

\section{Secondhand Smoke Exposure}

SHS is comprised of sidestream smoke (SS) and mainstream smoke (MS). ${ }^{24,25} \mathrm{MS}$ is the portion exhaled by smokers and accounts for $15 \%$ of total SHS exposure. SS is the portion of SHS that is released from the burning tip of a cigarette and accounts for $85 \%$ of total SHS exposure. In addition, the particle size of SS is one-tenth the size of MS, increasing its ability to reach the most distal alveoli in the lung. ${ }^{26}$ SHS is also referred to as passive smoking, environmental tobacco smoke, and involuntary smoking. To prevent confusion between these different descriptive terms, this review will use the term "secondhand smoke." Some of the irritant gases in SHS that can contribute to the development of airway disease are ammonia, nitrogen dioxide, sulfur dioxide, hydrogen cyanide, and acrolein. ${ }^{24,25}$ 


\section{Assessment of SHS Exposure}

Accurately quantifying exposure to SHS is problematic because of the multiple variables involved. The number of cigarettes smoked, length of time that smoking occurs, ventilation properties of the building, and absorptive qualities of elements contained in the building all contribute to exposure. $^{24,25}$ This evaluation of exposure is through the use of either biomarkers measured in the urine, saliva, blood, or hair; self-reported questionnaires; or home air monitors. ${ }^{24,27}$ The nicotine metabolite cotinine is the biomarker of choice because its halflife is much longer (17-24 hours) than nicotine (2-3 hours). ${ }^{28,29}$ However, children with asthma may have lower clearance rates of nicotine, resulting in higher systemic exposure; African-American children differ in their rate of absorption and metabolism of nicotine, which further enhances the problems with obtaining these measurements. ${ }^{30,31}$

One study determined that the use of 2 simple questions worked as well as cotinine screening among inner-city children with asthma. These two questions asked whether the primary caregiver smoked and if people were allowed to smoke within the child's home. These questions helped investigators to identify children with asthma with the greatest exposure to SHS and could predict which children would have elevated cotinine levels up to 9 months later. ${ }^{32}$ Another study developed a questionnaire containing 3 simple questions relayed from the primary caregiver to define children at highest risk of SHS exposure: Do you smoke? Do others who are often around the child smoke? and, Do you or others smoke inside of the home? The questionnaire was validated using child hair cotinine concentrations. ${ }^{33}$

\section{Effects of SHS Exposure among Children with Asthma}

Smoking, in general, is the number one leading cause of preventable death in the United States. ${ }^{34}$ Unfortunately, this statistic does not differentiate between primary and SHS exposure. There were a few manuscripts published in the 1990s referring to SHS exposure as the third leading cause of death, but this was in relation to causing heart diseaserelated not asthma-related deaths. ${ }^{35-37}$ SHS exposure is associated with chronic obstructive pulmonary disease, asthma, respiratory tract infections, and other body system damage. ${ }^{1,38}$ SHS from parents who smoke is associated with increased prev- alence of asthma and respiratory symptoms among school children. SHS from parents' smoking habits also is associated with more severe disease among those children with established asthma. ${ }^{39-41}$ Even exposure to "light cigarette smoking" ( $\leq 10$ cigarettes per day) can cause children who have asthma to experience nocturnal symptoms. ${ }^{42}$ Of all the forms of SHS, maternal exposure seems to have the largest impact on asthma by increasing the frequency and severity of the disease. ${ }^{1}$ Maternal smoking, in general, has been found to cause an increase of wheezing illness, especially during the first year of life, and to decrease lung function in children up to 6 years of age. ${ }^{43-46}$ Table 2 summarizes in utero exposure to SHS that results in asthma.

To date, there have not been any studies focusing directly on the effect of paternal SHS. However, one study observed the effects of SHS on asthma symptoms and medications in children and found that about $82 \%$ of the SHS exposure was via the father. ${ }^{58}$ SHS exposure occurred during the postnatal period and the determination of worsening of symptoms was through a subjective questionnaire and not actual laboratory measurements. Symptoms among the group with high SHS exposure were worse than those among the group with low to moderate SHS exposure, which was significant $(P=.0024)$.

Epidemiologic evidence linking asthma and cigarette consumption, provided by the United States National Health Interview Study and the American Lung Association, supports the contributing role of SHS in the epidemic of childhood asthma. ${ }^{59}$ Severity of asthma has been correlated to levels of SHS exposure. Morkjaroenpong et $\mathrm{al}^{42}$ found that children who were exposed to higher levels of SHS were 3 times as likely to be in the mild persistent

\section{Table 2. In Utero Exposure to Secondhand Smoke, Resulting in Asthma}

\begin{tabular}{lc}
\hline Results of Exposure & References \\
\hline $\begin{array}{l}\text { Offspring are 1.8 times more likely to develop } \\
\text { asthma and a lifetime history of wheezing }\end{array}$ & 47,48 \\
$\begin{array}{l}\text { Children diagnosed with early-onset asthma have } \\
\text { more persistent deficits in lung function }\end{array}$ & 49 \\
$\begin{array}{l}\text { Other effects } \\
\text { Significant reductions in forced expiratory flow }\end{array}$ & \\
$\quad \begin{array}{l}\text { Suppression of alveolarization, functional } \\
\text { residual capacity, and tidal flow volume }\end{array}$ &
\end{tabular}


category (26.8\% vs $15.9 \%$; OR, 3.4; 95\% CI, $1.3-$ 8.8) and twice as likely to be in the moderate to severe persistent category $(54.9 \%$ vs $47.6 \%$; OR, 2.3; 95\% CI, 1-5.1) compared with those with lower levels of SHS (from "light" smoking [ $\leq 10$ cigarettes/day]). Other investigators have also reported poor control of asthma in children because of SHS. ${ }^{60-62}$

The data from children exposed to SHS who report to the emergency department are conflicting. After the implementation of a smoke-free law in Kentucky, the state once known to have the highest smoking rates in the United States, it was reported that emergency department visits because of asthma declined by $22 \%$,suggesting a possible relationship between SHS exposure and asthma. ${ }^{63}$ The prevalence of smoking and nicotine addiction was high among parents of children who are brought to the emergency department because of asthma or bronchiolitis in one study, ${ }^{64}$ but, in another, SHS was found to have a weak association with acute asthma severity. ${ }^{65}$

Counseling about the detrimental effects of SHS in the emergency department may have a positive impact on the smoking habits of caregivers when they are around their children by educating them about the possibility of smoking as a trigger to their child's asthma, but more investigations are needed to verify. A study investigating the amount of SHS exposure after 20 minutes of asthma education in the emergency department found that there was a statistically significant decrease in the number of emergency department visits and hospitalizations because of asthma over a period of 1 year among children whose SHS exposure had decreased. ${ }^{66}$ The measurement of SHS exposure in this study was via a telephone survey and not cotinine levels. Table 3 lists effects of SHS on children with asthma.

\section{Effects of SHS Exposure on Adult Patients with Asthma}

LeSon and Gershwin ${ }^{77}$ assessed risk factors for young adult asthmatics who required intubation. Patients aged 20 to 34 years who were admitted during a 10-year period were evaluated. Among 550 hospital admissions, 34 required intubation. Although several risk factors were identified, such as psychosocial problems, prior intubation, and respiratory infection, active smoking or exposure to SHS were also important risk factors for intubation
Table 3. Effects of Secondhand Smoke (SHS) on Children with Asthma

\begin{tabular}{ll}
\hline Effects & References \\
\hline $\begin{array}{l}\text { Maternal exposure seems to be the most } \\
\text { significant of SHS exposure, which may be }\end{array}$ & $30,67-69$ \\
because of the child's close proximity to the & \\
mother & 70 \\
The association between parental SHS & \\
exposure and asthma becomes less strong & \\
after adolescence into adulthood, which may & \\
be because the child is spending less time at & \\
home & 71 \\
Asthmatic children exposed to multiple & \\
household smokers face a 4.5-fold increase & \\
risk for respiratory illness related absences \\
from school
\end{tabular}

(OR 7.1; 95\% CI, 5.1-9.9). Ebbert et $\mathrm{al}^{78}$ studied a possible association between respiratory tract diseases (including asthma) and SHS exposure among flight attendants who had never smoked. These flight attendants had worked during the time when smoking was still allowed on airplanes. Of 15,000 mailed questionnaires, 2053 (14\%) were returned. After excluding respondents with a history of smoking and one with a history of pulmonary disease before the age of 18 years, 1007 respondents remained for analysis. The great majority $(>85 \%)$ of the flight attendants were women and white, and the mean age was 54 years. Asthma was reported in $13.6 \%$, nasal allergies in $13.4 \%$, and sinusitis in $43.4 \%$ of respondents. Jindal et $\mathrm{al}^{79}$ compared asthma morbidity in 100 adults exposed to SHS (via a spouse and other close contacts) versus 100 adults who were not exposed during the preceding 12 months. The number of emergency department visits, other exacerbations, missed work, and corticosteroid requirement were greater in the group that was exposed to SHS $(P<.01)$. 


\section{Resistance to Corticosteroids in Asthmatic Patients Who Smoke}

A 1996 study by Pedersen et $\mathrm{al}^{80}$ examined the impact of low- and high-dose inhaled budesonide or oral theophylline treatment on lung function, bronchial hyper-reactivity, and blood inflammatory markers in 85 asthmatic patients. A post hoc subgroup analysis of asthmatic smokers versus nonsmokers in the study showed that the smokers had no improvement in $\mathrm{FEV}_{1}$, histamine $\mathrm{PC}_{20}$, blood eosinophil counts, eosinophil cationic protein, or eosinophil protein $\mathrm{x}$ after 9 months of treatment with either dose of inhaled budesonide. This was the first study to report corticosteroid resistance in asthmatic smokers. ${ }^{80}$ Subsequently, Chalmers et $\mathrm{al}^{81}$ performed a prospective, randomized, doubleblind, crossover, placebo-controlled study examining the effects of either inhaled fluticasone propionate $(500 \mu \mathrm{g}$ twice daily) or placebo for 10 weeks in patients with mild asthma. The nonsmoking patients in the study experienced a significantly greater improvement in morning peak expiratory flow (PEF) than those who smoked $(P=.0006)$. No significant changes in $\mathrm{PEF}, \mathrm{FEV}_{1}$, geometric mean methacholine $\mathrm{PC}_{20}$, or sputum eosinophil counts were found among the patients that smoked. ${ }^{81}$

Resistance to short-term, high-dose oral corticosteroids in asthmatic smokers also has been reported. ${ }^{82}$ Fifty patients with chronic stable asthma were randomized to receive either oral prednisolone $40 \mathrm{mg}$ or placebo tablets for 14 days each, followed by a 2 -week washout phase. There was no improvement in prealbuterol $\mathrm{FEV}_{1}$, morning PEF, nighttime $\mathrm{PEF}$, daytime symptoms, nighttime symptoms, use of rescue medication, or asthma control score among the asthmatic smokers versus the nonsmokers. ${ }^{82}$ In contrast, 19 smokers with moderate to severe asthma responded as well as nonsmokers to 4 weeks of treatment with highdose inhaled fluticasone, suggesting that some asthmatic smokers may respond to high-dose inhaled corticosteroid (ICS) therapy. ${ }^{83}$

In 2005, Tomlinson et al ${ }^{84}$ compared the effect of either $400 \mu \mathrm{g}$ or $2000 \mu \mathrm{g}$ daily inhaled beclomethasone among asthmatic smokers and nonsmokers. After 12 weeks, nonsmokers had significantly higher mean morning PEF measurements than the smokers (adjusted difference, $-18 ; 95 \% \mathrm{CI},-35$ to -1 ). Among patients who received low-dose beclomethasone, the smokers had no improvement in mean morning PEF measurements compared with non- smokers ( -6 vs 19 ; adjusted difference, $-25 ; 95 \%$ CI, -45 to -4$)$. In contrast, there was no significant difference in the change in mean morning PEF measurements between the smokers and nonsmokers who received high-dose beclomethasone (11 vs 18 ; adjusted difference, $-15 ; 95 \%$ CI, -50 to 21 ). Smokers also had significantly more asthma exacerbations than the nonsmokers (6 vs 1 , respectively; $P=.007$ ). Corticosteroid resistance in asthmatic smokers might be overcome through the use of higher corticosteroid doses, though larger trials are needed to confirm these results. $^{84}$

Lazarus et $\mathrm{al}^{85}$ also reported corticosteroid resistance in 39 asthmatic smokers who received 8 weeks of therapy with inhaled hydrofluoroalkane beclomethasone $(160 \mu \mathrm{g}$ twice daily) compared with 44 nonsmokers. Compared with the nonsmokers, the smokers only experienced significant improvements in daily morning PEF (mean difference 8.30; 95\% CI, 0.80-15.81) and sputum eosinophil counts (mean difference -3.44 ; $95 \%$ CI, -6.56 to -0.32 ). Though the overall differences between the smokers and nonsmokers were not statistically significant, this could be because the small sample size. ${ }^{85}$

A post hoc analysis of the Gaining Optimal Control in Asthma trial showed that asthmatic smokers who received fluticasone for 1 year experienced increased rates of asthma exacerbations compared with people who had never smoked ( 0.35 vs 0.17 per patient per year, respectively). Asthmatic smokers in the study also had a higher probability of having poorly controlled asthma versus nonsmokers (OR, 2.757; 95\% CI, 2.061-3.689). ${ }^{86} \mathrm{In}$ addition to having poorer disease control, asthmatic smokers may not derive benefit from corticosteroids in terms of preserving lung function. A 23-year observational study of 122 asthmatic patients in The Netherlands revealed that men with $>5$ pack years of smoking failed to show improvement in the yearly decline of $\mathrm{FEV}_{1}$ after therapy with ICS was initiated $(27.8 \mathrm{~mL} /$ year before treatment [range, $14.3-41.3 \mathrm{~mL} /$ year]); $16.1 \mathrm{~mL} /$ year after treatment [range, 3.3-28.9 mL/year]). ${ }^{87}$ In contrast, a 10-year observational study of 234 asthmatic patients reported that smokers experienced significant improvement in $\mathrm{FEV}_{1}$ after treatment with ICS (57.9 $\mathrm{mL} /$ year vs $30.8 \mathrm{~mL} /$ year; $P=.035) .{ }^{88}$ In addition, a post hoc analysis of the Inhaled Steroid Treatment as Regular Therapy Trial by O'Byrne and colleagues ${ }^{89}$ reported that patients with newly diagnosed mild asthma who smoked did show significant improvements in post bronchodilater FEV1 measurements 
after 3 years of treatment with inhaled budesonide $400 \mu \mathrm{g}$ daily $(71.5 \mathrm{~mL}$ in smokers $[P=.011]$ vs 46.5 $\mathrm{mL}$ in nonsmokers $[P=.001])$. More studies are needed to fully elucidate the effects of smoking on lung function decline among asthmatic smokers.

\section{Resistance to Inbaled Corticosteroids in Asthmatics Exposed to SHS}

A 2004 study by Halterman et $\mathrm{al}^{90}$ comparing school-based supervised ICS treatment versus usual care of asthma among 180 children between the ages of 3 and 7 showed that quality of life, absence rates, and number of symptom free days improved in the school-based group compared with usual care; however, significant improvements were only seen in children who were not exposed to SHS. Children who were not exposed to SHS also had fewer days requiring quick relievers $(P=.03)$ and were less likely to have 3 or more acute care visits for asthma $(P=.03){ }^{90}$

\section{Mechanisms of Corticosteroid Resistance}

There are several proposed mechanisms of corticosteroid resistance in asthmatic smokers. Table 4 summarizes the effects of smoking and SHS on the response to oral corticosteroids and ICS. Airway mucosal permeability is increased in smokers with normal lung function and in asthmatic patients who do not smoke. ${ }^{99,100}$ Another proposed mechanism of corticosteroid resistance is the down-regulation of $\beta_{2}$-adrenergic receptors in lymphocytes that is caused by cigarette smoking. ${ }^{101}$ Changes in levels of cytokines and inflammatory mediators may also play a role. Cigarette smoke has been shown to increase the production of interleukin 4 , interleukin 8 , and tumor necrosis factor- $\alpha$ and decrease the production of interleukin 10. ${ }^{102-105}$ Another potential mechanism for corticosteroid resistance is the overexpression of GR- $\beta$ receptors and underexpression of GR- $\alpha$ receptors. GR- $\alpha$ receptors are functional, whereas GR- $\beta$ receptors are not; therefore, an increase in the number of GR- $\beta$ receptors could lead to decreased binding and activity of glucocorticoids in vivo. ${ }^{106,107}$ Altered corticosteroid cell-signaling systems may also play a role.

\section{Conclusion}

The evidence reviewed in this article regarding the multiple negative effects of smoking and SHS on patients with asthma should underscore the obliga-
Table 4. Effects of Smoking and Secondhand Smoke (SHS) on Response to Corticosteroids

\begin{tabular}{|c|c|}
\hline Effects & References \\
\hline $\begin{array}{l}\text { It is unknown if there is a synergistic effect } \\
\text { of smoking and asthma on airway } \\
\text { mucosal permeability; however, this } \\
\text { could contribute to increased clearance } \\
\text { of inhaled corticosteroids from the } \\
\text { airways of asthmatic smokers }\end{array}$ & 91 \\
\hline $\begin{array}{l}\text { Chronic hypersecretion of mucus is caused } \\
\text { by cigarette smoking in patients with } \\
\text { asthma, and this could impede the ability } \\
\text { of inhaled corticosteroids to bind to GRs } \\
\text { in the airways }\end{array}$ & 92 \\
\hline $\begin{array}{l}B_{2} \text {-agonists increase the nuclear localization } \\
\text { of GRs, which may potentiate the effects } \\
\text { of corticosteroids }\end{array}$ & 93 \\
\hline $\begin{array}{l}\text { Cigarette smoke leads to increased } \\
\text { numbers of neutrophils and CD } 8+ \\
\text { lymphocytes and decreased numbers of } \\
\text { eosinophils in the airways, which may } \\
\text { contribute to corticosteroid resistance }\end{array}$ & 91 \\
\hline $\begin{array}{l}\text { Nitric oxide in cigarette smoke has been } \\
\text { shown to decrease the binding affinity of } \\
\text { glucocorticoid receptors (GR) in vitro; it } \\
\text { remains to be seen whether or not nitric } \\
\text { oxide shows the same effect in vivo } 94\end{array}$ & 94 \\
\hline $\begin{array}{l}\text { Other proposed mechanisms include } \\
\text { overexpression of proinflammatory } \\
\text { transcription factors such as NF-к } \beta \text {, } \\
\text { activator protein-1, and signal } \\
\text { transduction-activated factor }\end{array}$ & 95,96 \\
\hline $\begin{array}{l}\text { HDAC activity is necessary for } \\
\text { corticosteroids to fully suppress cytokine } \\
\text { production, and smokers have decreased } \\
\text { HDAC activity in alveolar macrophages, } \\
\text { which could lead to corticosteroid } \\
\text { resistance }\end{array}$ & 97 \\
\hline $\begin{array}{l}\text { The p38 mitogen-activated protein kinase } \\
\text { signaling pathway may be activated in } \\
\text { asthmatic smokers which phosphorylates } \\
\text { GRs and decreases corticosteroid affinity }\end{array}$ & 98 \\
\hline
\end{tabular}

GR, glucocorticoid receptor; HDAC, histone deacetylase.

tion of primary care physicians and other health care professionals to assist patients and those they live with to quit smoking. Specific instructions for family members, caregivers, and friends of patients with asthma should include never smoking in the home, car, or workplace. Simply smoking in another room of the house is not sufficient, nor are any forms of air cleaners effective in reducing SHS exposure. $^{108}$

The specific methods of tobacco abuse counseling and treatment are beyond the scope of this review, but recent studies shed some light on the effectiveness of interventions. Parental perceptions about the harmful effects of SHS exposure on their asthmatic child are often underestimated, as is the degree of SHS expo- 
sure. ${ }^{109}$ With successful smoking cessation, a parent can add an average of 7 years to his or her life, eliminate SHS exposure to other family members, and reduce tobacco-related pregnancy outcomes. ${ }^{110}$

In a survey of parental smokers, $80 \%$ self-reported making attempts to quit in the past, with an average of 3 attempts each. Only $4.4 \%$ of those surveyed received assistance from a health care provider. ${ }^{111} \mathrm{~A}$ study of pediatric resident training on tobacco cessation found that, although $70 \%$ of the parents reported that residents asked about cigarette smoking and half of these patients indicated the resident talked with them about SHS, only $10 \%$ of smokers stated their physician offered to help them stop smoking, and $25 \%$ of all parental/guardians indicated that their physician offered to help them stop exposing their child to SHS in the home or elsewhere. ${ }^{111}$

Given the significance of the effects of SHS and primary smoking on asthma control and treatment, as health care professionals there is ample room for improvement in our interventions to reduce exposure to cigarette smoke. We urge family medicine physicians to discuss primary smoking in addition to SHS exposure with all of their patients because this could potentially change a patient's and/or their loved ones' quality of life.

\section{References}

1. National Institutes of Health. Expert Panel Report 3. Guidelines for the diagnosis and management of asthma. NIH Publication No. 07-4051Bethesda, MD: National Institutes of Health; 2007.

2. Peters JM, Avol E, Navidi W, et al. A study of twelve Southern California communities with differing levels and types of air pollution: I. Prevalence of respiratory morbidity. Am J Respir Crit Care Med 1999;159:760-7.

3. Van der Vaart H, Postma DS, et al. Acute effects of cigarette smoking on inflammation in healthy intermittent smokers. Respir Res 2005;6:22.

4. Boulet L-P, Lemiere C, Archambault F, et al. Smoking and asthma: clinical and radiologic features, lung function, and airwary inflammation. Chest 2006;129:661-8.

5. Floreani A and Rennard S. The role of cigarette smoke in the pathogenesis of asthma and as a trigger for acute symptoms. Curr Opin Pulm Med 1999;5:38-46.

6. Yanbaeva DG, Dentener MA, Creutzberg EC, et al. Systemic effects of smoking. Chest 2007;131: 1557-66.

7. Chalmers G, MacLeod KJ, Thomson L, et al. Smoking and airway inflammation in patients with mild asthma. Chest 2001;120:1917-22.
8. Kent L, Smyth L, Clayton C, et al. Cigarette smoke extract induced cytokine and chemokine gene expression changes in COPD macrophages. Cytokine 2008;42:205-16.

9. Birrell MA, Wong S, Catley MC, et al. Impact of tobacco smoke on key signaling pathways in the innate immune response in lung macrophages. J Cell Physiol 2008;214:27-37.

10. Kostikas K, Gaga M, Papatheodorou G, et al. Leukotriene B4 in exhaled breath condensate and sputum supernatant in patients with COPD and asthma. Chest 2005;127:1553-9.

11. Arnson Y, Shoenfeld Y, Amital H. Effects of tobacco smoke on immunity, inflammation, and autoimmunity. J Autoimmun 2010;34:258-65.

12. McKay A, Komai-Koma M, MacLeod K, et al. Interleukin-18 levels in induced sputum and reduced in asthmatic and normal smokers. Clin Exp Allergy 2004;34:904-10.

13. Kanazawa $\mathrm{H}$, Tochino $\mathrm{Y}, \mathrm{Kyoh} \mathrm{S}$, et al. Increased levels of angiopoietin-2 in induced sputum from smoking asthmatic patients. Clin Exp Allergy 2009; 39:1330-7.

14. Krisiukeniene A, Babusyte A, Stravinskaite K, et al. Smoking affects eotaxin levels in asthma patients. J Asthma 2009;46:470-6.

15. Piipari R, Jaakkola JJK, Jaakkola N, et al. Smoking and asthma in adults. Eur Respir J 2004;24:734-9.

16. Gilliland FD, Islan T, Berthane K, et al. Regular smoking and asthma incidence in adolescents. Am J Respir Crit Care Med 2006;174:1094-100.

17. Schatz M, Zeiger RS, Vollmer WM, et al. Determinants of future long-term asthma control. J Allergy Clin Immunol 2006;118:1048-53.

18. McCoy K, Shade DM, Irvin CG, et al. Predicting episodes of poor asthma control in treated patients with asthma. J Allergy Clin Immunol 2006;118:1226-33.

19. Strine TW, Balluz LS, Ford ES. The associations between smoking, physical inactivity, obesity, and asthma severity in the general US population. J Asthma 2007;44:651-8.

20. Chaudhuri R, McSharry C, McCoard A, et al. Role of symptoms and lung function in determining asthma control in smokers with asthma. Allergy 2008;63:132-5.

21. Chapman KR, Boulet LP, Rea RM, et al. Suboptimal asthma control: prevalence, detection, and consequences in general practice. Cur Respir J 2008; 31:320-5.

22. Laforest L, Van Ganse E, Devouassoux G, et al. Influence of patients' characteristics and disease management on asthma control. J Allergy Clin Immunol 2006;117:1404-10.

23. Leuppi, JD, Steurer-Stey C, Peter M, et al. Asthma control in Switzerland: a general practitioner based study. Curr Med Res Opin 2006;22(11):2159-66.

24. US Department of Health and Human Services. The health consequences of involuntary exposure 
to tobacco smoke: a report of the Surgeon General. Atlanta, GA: Centers for Disease Control and Prevention, Office of Smoking and Health; 2006.

25. Reardon JZ. Environmental tobacco smoke: respiratory and other health effects. Clin Chest Med 2007;28:559-73.

26. Chan-Yeung M, Dimich-Ward H. Respiratory health effects of exposure to environmental tobacco smoke. Respirology 2003;8:131-9.

27. Kumar R, Curtis LM, Khiani S, et al. A community-based study of tobacco smoke exposure among inner-city children with asthma in Chicago. J Allergy Clin Immunol 2008;122:754-9.

28. Benowitz NL. Continine as a biomarker of environmental tobacco smoke exposure. Epidemiol Rev 1996;18:188-204.

29. Leong JW, Dore ND, Shelley K, et al. The elimination half-life of urinary continine in children of tobacco-smoking mothers. Pulm Pharmacol Ther 1998;11:287-90.

30. Knight JM, Eliopoulos C, Klein J, et al. Passive smoking in children: racial differences in systemic exposure to continine by hair and urine analysis. Chest 1996;109:446-50.

31. Knight JM, Eliopoulos C, Klein J, et al. Pharmacokinetic predisposition to nicotine from environmental tobacco smoke: a risk factor for pediatric asthma. J Asthma 1998;35:113-7.

32. Halterman JS, Borelli B, Tremblay P, et al. Screening for environmental tobacco smoke exposure among inner-city children with asthma. Pediatrics 2008;122:1277-83.

33. Groner JA, Hoshaw-Woodard S, Koren G, et al. Screening for children's exposure to environmental tobacco smoke in pediatric primary care setting. Arch Pediatr Adolesc Med 2005;159:450-5.

34. Center for Disease Control. Tobacco use: targeting the nation's leading killer at a glance 2011. Available at: http://www.cdc.gov/chronicdisease/resources/ publications/aag/osh.htm. Accessed November 2010.

35. Glantz SA and Parmley WW. Passive smoking and heart disease: epidemiology, physiology, and biochemistry. Circulation 1991;83:1-12.

36. Taylor AE, Johnson DC, and Kazemi H. Environmental Tobacco Smoke and Cardiovascular Disease: a position paper from the council on cardiopulmonary and critical care. American Heart Association. Circulation 1992;86:699-702.

37. Glantz SA, Parmley WW. Passive smoking and heart disease: mechanism and risk. JAMA 1995;273: 1047-53.

38. Global Initiative for Chronic Obstructive Lung Disease (GOLD). Guidelines: global strategy for the diagnosis, management, and prevention of chronic obstructive pulmonary disease. 2009. Available at: http:// www.goldcopd.com/Guidelineitem.asp? $11=2 \& 12=1 \&$ intId=2003. Accessed November 2010.
39. Maier WC, Arrighi HM, Morray B, et al. Indoor risk factors for asthma and wheezing among Seattle school children. Environ Health Perspect 1997; 105:208-14.

40. Lam TH, Chung SF, Betson CL, et al. Respiratory symptoms due to active and passive smoking in junior secondary school students in Hong Kong. Int J Epidemiol 1998;27:41-8.

41. Butland BK, Strachan DP, Anderson HR. The home environment and asthma symptoms in childhood: two population based case-control studies 13 years apart. Thorax 1997;52:618-24.

42. Morkjaroenpong V, Rand CS, Butz AM, et al. Environmental tobacco smoke exposure and nocturnal symptoms among inner-city children with asthma. J Allergy Clin Immunol 2002;110:147-53.

43. Martinez FD, Wright AL, Taussig LM, et al. Asthma and wheezing in the first six years of life. N Engl J Med 1995;332:133-8.

44. Strachan DP, Cook DG. Parental smoking and childhood asthma: longitudinal and case-control studies. Thorax 1998;53:204-12.

45. Kurukulaaratchy RJ, Waterhouse L, Matthews SM, et al. Are influences during pregnancy associated with wheezing phenotypes during the first decade of life? Acta Paediatrica 2005;94:553-8.

46. Lannero E, Wickman M, Pershagen G, et al. Maternal smoking during pregnancy increases the risk of wheezing during the first years of life (BAMSE). Respir Res 2006;7:3.

47. Gilliland FD, Berhane K, McConnell R, et al. Maternal smoking during pregnancy, environmental tobacco smoke exposure and childhood lung function. Thorax 2000;5 5:271-6.

48. Pattenden S, Antova T, Neuberger M, et al. Parental smoking and children's respiratory health: independent effects of prenatal and postnatal exposure. Tob Control 2006;15:294-301.

49. Gilliland FD, Berhane K, Li YF, et al. Effects of early onset asthma and in utero exposure to maternal smoking on childhood lung function. Am J Respir Crit Care Med 2003;167:917-24.

50. Cunningham J, Dockery DW and Speizer FE. Maternal smoking during pregnancy as a predictor of lung function in children. Am J Epidemiol 1994; 139:1139-52.

51. Tager IB, Ngo L, Hanrahan JP. Maternal smoking during pregnancy. Effects on lung function during the first 18 months of life. Am J Respir Crit Care Med 1995;152:977-83.

52. Stick SM, Burton PR, Gurrin L, et al. Effects of maternal smoking during pregnancy and a family history of asthma on respiratory function in newborn infants. Lancet 1996;348:1060-4.

53. Carlsen KCL, Jaakkola JJK, Nafstad P, et al. In utero exposure to cigarette smoking influences lung function at birth. Eur Respir J 1997;10: 1774-9. 
54. Hoo AF, Henschen M, Dezateux C, et al. Respiratory function among preterm infants whose mothers smoked during pregnancy. Am J Respir Crit Care Med 1998;158:700-5.

55. Dezateux C, Stocks J, Dundas I, et al. Impaired airway function and wheezing in infancy: the influence of maternal smoking and a genetic predisposition to asthma. Am J Respir Crit Care Med 1999; 159:403-10.

56. Gilliland FD, Li YF, Peters JM. Effects of maternal smoking during pregnancy and environmental tobacco smoke on asthma and wheezing in children. Am J Respir Crit Care Med 2001;163:429-36.

57. Li YF, Langholz B, Salam MT, et al. Maternal and grandmaternal smoking patterns are associated with early childhood asthma. Chest 2005;127:1232-41.

58. Yamasaki A, Hanaki K, Tomita K, et al. Environmental tobacco smoke and its effect on the symptoms and medication in children with asthma. Int J Environ Health Res 2009;19:97-108.

59. Goodwin RD. Environmental tobacco smoke and the epidemic of asthma in children: the role of cigarette use. Ann Allergy Asthma Immunol 2007; 98:447-54.

60. De Boeck K, Moens M, Van Der Aa N, et al. 'Difficult asthma': can symptoms be controlled in a structured environment? Pediatr Pulmonol 2009; 44:743-8.

61. Lawson JA, Dosman JA, Rennie DC, et al. Relationship between indoor environment and asthma and wheeze severity among rural children and adolescents. J Agromedicine 2009;14:277-85.

62. McGhan SL, MacDonald C, James DE, et al. Factors associated with poor asthma control in children aged five to 13 years. Can Respir J 2006;13:23-9.

63. Rayens MK, Burkhart PV, Zhang M, et al. Reduction in asthma-related emergency department visits after implementation of a smoke-free law. J Allergy Clin Immunol 2008;122:537-41.

64. Mahabee-Gittens M. Smoking in parents of children with asthma and bronchiolitis in a pediatric emergency department. Ped Emerg Care 2002;18:4-7.

65. Vargas PA, Brenner B, Clark S, et al. Exposure to environmental tobacco smoke among children presenting to the emergency department with acute asthma: a multicenter study. Pediatr Pulmon 2007; 42:646-55.

66. Gerald LB, Gerald JK, Gibson L, et al. Changes in environmental tobacco exposure and asthma morbidity among urban school children. Chest 2009; 135:911-6.

67. Cook DG, Whincup PH, Jarvis MJ, et al. Passive exposure to tobacco smoke in children aged 5-7 years: individual, family, and community factors. BMJ 1994;308:384-9.

68. Oddoze C, Dubus JC, Badier M, et al. Urinary continine and exposure to parental smoking in a population of children with asthma. Clin Chem 1999;45:505-9.

69. Irvine L, Crombie IK, Clark RA, et al. What determines levels of passive smoking in children with asthma? Thorax 1997;52:766-9.

70. Wilson SR, Yamada EG, Sudhakar R, et al. A controlled trial of an environmental tobacco reduction intervention in low-income children with asthma. Chest 2001;120:1709-22.

71. Gilliland FD, Behane K, Islam T, et al. Environmental tobacco smoke and absenteeism related to respiratory illness in school-children. Am J Epidemiol 2003;157:861-9.

72. Li YF, Gilliland FD, Berhane K, et al. Effects of in utero and environmental tobacco smoke exposure on lung function in boys and girls with and without asthma. Am J Respir Crit Care Med 2000;162: 2097-104.

73. Arshad SH, Kurukulaaratchy RJ, Fenn M, et al. Early life risk factors for current wheeze, asthma, and bronchial hyperresponsiveness at 10 years of age. Chest 2005;127:502-8.

74. Mannino DM, Homa DM, Redd SC. Involuntary smoking and asthma severity in children: Data from the third national health and nutrition examination survey. Chest 2002;122:409-15.

75. Schwartz J, Timonen KL, Pekkanen J. Respiratory effects of environmental tobacco smoke in a panel study of asthmatic and symptomatic children. Am J Respir Crit Care Med 2000;161:802-6.

76. Leson S, Gershwin ME. Risk factors for asthmatic patients requiring intubation. I. Observations in children. J Asthma 1995;32:285-94.

77. LeSon S, Gershwin ME. Risk factors for asthmatic patients requiring intubation. III. Observations in young adults. J Asthma 1996;33:27-35.

78. Ebbert JO, Croghan IT, Schroeder DR, et al. Association between respiratory tract diseases and secondhand smoke exposure among never smoking flight attendants: a cross-sectional survey. Environ Health 2007;6:28.

79. Jindal SK, Gupta D, Singh A. Indices of morbidity and control of asthma in adult patients exposed to environmental tobacco smoke. Chest 1994;106: 746-9.

80. Pedersen B, Dahl R, Karlstrom R, et al. Eosinophil and neutrophil activity in asthma in a one-year trial with inhaled budesonide. Am J Respir Crit Care Med 1996;153:1519-29.

81. Chalmers GW, Macleod KJ, Little SA, et al. Influence of cigarette smoking on inhaled corticosteroid treatment in mild asthma. Thorax 2002;57:226-30.

82. Chaudhuri R, Livingston E, McMahon AD, et al. Cigarette smoking impairs the therapeutic response to oral corticosteroids in chronic asthma. Am J Respir Crit Care Med 2003;168:1308-11.

83. Jang As, Lee JH, Park SW, et al. Factors influencing the responsiveness to inhaled glucocorticoids of 
patients with moderate-to-severe asthma. Chest 2005;128:1140-5.

84. Tomlinson JEM, McMahon AD, Chaudhuri R, et al. Efficacy of low and high dose inhaled corticosteroid in smokers versus non-smokers with mild asthma. Thorax 2005;60:282-7.

85. Lazarus SC, Chinchilli VM, Rollings NJ, et al. Smoking affects response to inhaled corticosteroids or leukotriene receptor antagonists in asthma. Am J Respir Crit Care Med 2007;175:783-90.

86. Pedersen SE, Bateman ED, Bousquet J, et al. Determinants of response to fluticasone propionate and salmeterol/fluticasone propioinate combination in the Gaining Optimal Asthma Control study. J Allergy Clin Immunol 2007;120:1036-42.

87. Dijkstra A, Vonk JM, Jongepier H, et al. Lung function decline in asthma: association with inhaled corticosteroids, smoking, and sex. Thorax 2006;61:105-10.

88. Lange $\mathrm{P}$, Scharling H, Ulrik CS, et al. Inhaled corticosteroids and decline of lung function in community residents with asthma. Thorax 2006;61:100-4.

89. O'Byrne PM, Lamm CJ, Busse WW, et al. The effects of inhaled budesonide on lung function in smokers and nonsmokers with mild persistent asthma. Chest 2009;136:1514-20.

90. Halterman JS, Szilagyi PG, Yoos JL, et al. Benefits of a school-based asthma treatment program in the absence of secondhand smoke exposure. Arch Pediatr Adolesc med 2004;158:460-7.

91. Thomson NC, Chaudhuri R, Livingston E. Asthma and cigarette smoking. Eur Respir J 2004;24:822-33.

92. Lange P, Parner J, Vestbo J, et al. A 15-year follow-up study of ventilatory function in adults with asthma. N Engl J Med 1998;339:1194-1200.

93. Barnes P. Scientific rationale for inhaled combina-

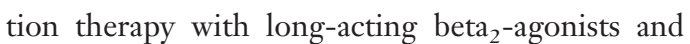
corticosteroids. Eur Respir J 2002;19:182-91.

94. Galigniana MD, Piwien-Pilipuk G, Assreuy J. Inhibition of glucocorticoid receptor binding by nitric oxide. Mol Pharmacol 1999;55:317-23.

95. Wang H, Yu M, Ocham M, et al. Nicotinic acetylcholine receptor 7 subunit is an essential regulator of inflammation. Nature 2003;421:348-88.

96. Rahman I, MacNee W. Role of transcription factors in inflammatory lung disease. Thorax 1998;53: 601-12.

97. Ito K, Lim S, Caramori G, et al. Cigarette smoking reduces histone deacetylase 2 expression, enhances cytokine expression, and inhibits glucocorticoid actions in alveolar macrophages. FASEB J 2001;15: 1110-2.

98. Irusen E, Matthews J, Takahashi A, et al. p38 Mitogen-activated protein kinase-induced glucocorti- coid receptor phosphorylation reduces its activity: role in steroid-insensitive asthma. J Allergy Clin Immunol 2002;109:649-57.

99. Kennedy S, Elwood R, Wiggs B, et al. Increased airway mucosal permeability of smokers: relationship to airway reactivity. Am Rev Respir Dis 1984; 129:143-8.

100. Ilowite J, Bennett W, Sheetz M, et al. Permeability of the bronchial mucosa to ${ }^{99 m}$ Tc-DTPA in asthma. Am Rev Respir Dis 1988;139:1139-43.

101. Laustiola K, Lassilia R, Kaprio J, et al. Decreased beta-adrenergic receptor density and catecholamine response in male cigarette smokers: a study of monozygotic twin pairs discordant for smoking. Circulation 1988;78:1234-40.

102. Byron K, Varigos G, Wootton A. IL-4 production is increased in cigarette smokers. Clin Exp Immunol 1994;95:333-6.

103. Keatings V, Collins P, Scott D, et al. Differences in interleukin-8 and tumour necrosis factor- $\alpha$ in induced sputum from patients with chronic obstructive pulmonary disease disease and asthma. Am J Respir Crit Care Med 1996;153:530-4.

104. Churg A, Dai J, Changshi X, et al. Tumour necrosis factor- $\alpha$ is central to acute cigarette smoke-induced inflammation and connective tissue breakdown. Am J Respir Crit Care Med 2002;166:849-54.

105. Hawrylowicz C, Richards D, Loke T-K, et al. A defect in corticosteroid-induced IL-10 production in $\mathrm{T}$ lymphocytes from corticosteroid-resistant patients. J Allergy Clin Immunol 2002;109:369-70.

106. Oakley RH, Jewell CM, Yudt MR, et al. The dominant negative activity of the human glucocorticoid receptor beta isoform. Specificity and mechanisms of action. J Biol Chem 1999;274:27857-66.

107. Pujols L, Mullol J, Perez M, et al. Expression of the human glucocorticoid receptor alpha and beta isoforms in human respiratory epithelial cells and their regulation by dexamethasone. Am J Respir Cell Mol Biol 2001;24:49-57.

108. Levy DT, Romano E, Mumford EA. Recent trends in home and work smoking bans. Tob Control 2004;13(3):258-63.

109. Farber HJ, Knowles SB, Brown NL, et al. Secondhand tobacco smoke in children with asthma. Chest 2008;133:1367-74.

110. Winickoff JP, Tanski SE, McMillen RC, et al. A National survey of the acceptability of quitlines to help parents quit smoking. Pediatrics 2006;117: 695-700.

111. Hymowitz N, Schwab J, Haddock CK, et al. The pediatric resident training on tobacco project: baseline findings from the parent/guardian tobacco survey. Prev Med 2005;41:334-41. 